Jurnal Hunafa: Studia Islamika, Volume 17, Number 2, p. 1-190

E-ISSN: 2355-7710

P-ISSN: 1411-125X

\title{
LEARNING CHARACTERS OF EARLY CHILDREN BASED ON MODERATE ISLAM
}

Gusnarib Wahab ${ }^{1}$ and Gunawan B. Dulumina ${ }^{2}$

${ }^{1}$ FTIK, IAIN Palu, Palu, iain.gusnarib@gmail.com,

2FTIK, IAIN Palu, Palu, gunawan_b_dulumina@yahoo.com

\begin{abstract}
The inclusion of character values and wisdom in early childhood is a very urgent matter because it is our shared responsibility to build the good attitudes and behavior of children and how to deal with personal problems. Education as a process of intelligence through learning so that teachers and parents must be responsible for making a person not only knows the values of goodness alone but can make the children realize the values of virtue in daily life for the realization of tough characters and noble personality. Learning moderate Islamic character values can be carried out properly and maximally when all parties. Cooperating and doing the same through a policy or regulation of school leaders, as a policymaker and the interests of an educational institution based on values. Learning activities, in addition to making students master competencies (material) that are targeted, are also designed to make students know, realize or care, and can internalize values and make them behave in their lives.
\end{abstract}

Keywords: Character, Early Childhood, Moderate Islam

Abstrak. Penanaman nilai-nilai karakter dan kearifan pada anak usia dini merupakan hal yang sangat mendesak karena sudah menjadi tanggung jawab kita bersama bahwa dalam kehidupan sehari-hari anak akan tercermin dari sikap dan perilaku anak serta cara menghadapi masalah pribadinya. Pendidikan sebagai proses kecerdasan melalui pembelajaran sehingga guru dan orang tua harus bertanggung jawab agar seseorang tidak hanya mengetahui nilai-nilai kebaikan saja tetapi dapat menjadikan anak-anak menyadari nilai-nilai kebajikan dalam kehidupan sehari-hari demi terwujudnya akhlak yang tangguh dan berkepribadian luhur. Pembelajaran nilai-nilai karakter islami moderat dapat terlaksana dengan baik dan maksimal bila semua pihak. Bekerja sama dan melakukan hal yang sama melalui kebijakan atau regulasi pimpinan sekolah, sebagai pembuat kebijakan dan kepentingan lembaga pendidikan yang berlandaskan nilai. Pada dasarnya kegiatan pembelajaran selain menjadikan peserta didik menguasai kompetensi (materi) yang ditargetkan, juga dirancang agar peserta didik 
mengetahui, menyadari atau peduli, serta dapat menginternalisasikan nilai-nilai dan menjadikan mereka berperilaku dalam kehidupannya.

Kata Kunci: Karakter, Masa Kanak-Kanak, Islam Moderat

\section{Preliminary}

Learning, which was originally termed the word teaching, has now changed the terms and nomenclature into learning, learning comes from the word teach, or teaching comes from ancient English, which is taecan. Ancient teacan means to teach ${ }^{1}$. Thus, to and teach have historically been related. To teach seen from the origin of the word means to show something to someone through signs or symbols. Since the 1500s, the definition of teaching has developed continuously. Descriptively teaching is defined as the process of conveying information or knowledge from educators to students ${ }^{2}$. The delivery process is often seen as a process of transfer of knowledge and value of education. Smith also explained that teaching knowledge or skills views ${ }^{3}$. Learning character values with a value approach to Islamic values is needed today considering and photographing models and forms of association, communication environment, and students' attitudes and behavior (children). It is important to pay attention to worry if we take pictures, it is our responsibility educators, parents at home, community leaders as well as stakeholders, strive to find and formulate techniques and models for learning the values of moderate Islamic character values so that social inequalities and educational problems can be unraveled and connected to

${ }^{1} \mathrm{~T}$. Dobinson, "Do Learners Learn from Classroom Interaction and Does the Teacher Have A Role to Play?" Language Teaching Research, Vol. 5, No. 3, (2001): 189-211. https://doi.org/10.1177/136216880100500302

${ }^{2}$ N. Nurdin \& Z. C. Aratusa, "Benchmarking Level Interactivity of Indonesia Government University Websites." TELKOMNIKA Telecommunication, Computing, Electronics and Control, 18(2), (2020): 853-859.

${ }^{3}$ L. Darling-Hammond, L. Flook, C. Cook-Harvey, B. Barron, \& D. Osher, "Implications for Educational Practice of The Science of Learning and Development." Applied Developmental Science, 24(2), (2020): 97-140. https://doi.org/10.1080/10888691.2018.1537791 
the common thread. Regarding the research location, the children's learning environment is not yet conducive, and the children's learning and play space are very narrow or limited. Optimal according to the objectives that have been set.

Based on the above understanding, three important things characterize a system. First, every system must have a goal. The goal is the main feature of a system when the goal is the direction to be achieved by a system movement. Second, the system always contains a process, and a process is a series of activities. Activities are directed at achieving goals, and the more complex a goal is, the more complex the activity process is Third. The process of activities in a system always involves the same and utilizes various components or elements.

The view of the learning concept offered through this study is two collaborative learning systems of different times but with the same view and point of view which have many similarities, in the application and implementation of a learning system called the "Among" learning system and the learning system "Constructivism" (contextual) learning concepts "Piaget" these two learning systems; Very appreciative of the importance of the initial experience or behavior of students (children), the essence is to explore the potential of students by providing opportunities for aspects of freedom to foster creativity and positive innovation as well as the freedom to work, sing and play as well as argue, (inquiry and discovery) the author tries see the slice of the learning system that appreciates and respects the existence of each individual (student or child) as a learner.

Based on these two learning systems, the writer conducts exploratory studies and research on the feasibility of the theory, concepts, and learning systems of Among (the initial concept of national education) and constructivism (the concept of contextual learning), observing, and implementing the formation of character values inculcation seen and viewed from Islamic values moderate. The teachers integrate the 
basic concept and description of character values according to the conceptual perspective of early childhood education theory.

Currently, there is still a lack of teachers and PAUD managers, and the value of moderate Islamic character values is not fully integrated with early childhood so that there is a need for an increase in mastery of materials, learning methods, and approaches and the need for teachers to seek enrichment and enrich learning media and educational games that are related to the material of praying, singing, playing and working following the material values of moderate Islamic character values, local wisdom character values, and Qur'anic wisdom character values.

The importance of cultivating moderate Islam-based character values is introduced to early childhood about the importance of maintaining the nature of "tolerance" between religious communities, the importance of mutual respect for differences, and respecting diversity in life, religion, and social culture ${ }^{4}$. It is important to maintain "equality," and there should be no differences in social classification and social strata that need to be preserved in daily life. The point is that we have a "sensitive" attitude to cultivate and maintain a caring and "sensitive" attitude towards our fellow human beings as well as to animal and plant creatures. Still maintaining and maintaining its existence on earth because we humans are the most literal creatures with Allah, the importance is that we maintain the nature of not differentiating from others or not being "discriminatory" in various matters in the individual, social and cultural lives of all those people we can work together to achieve and the goal should not be feeling unfriendly because in the eyes of Allah and in the eyes of the law we are the same why in the eyes of humans we must be different so we should not allow the nature and attitude of discrimination or claim to a certain group all of us, the importance of maintaining the nature and attitude of giving space and The same

${ }^{4}$ E. Evita, A. Syahid, \& N. Nurdin, “Understanding Students' Learning Outcomes Differences Through the Application of the Market Place Activity Type of Cooperative Learning Model and the Application of Conventional Learning Models." International Journal of Contemporary Islamic Education, 1(1), (2019): 67-85. 
"opportunity" for everyone gives "freedom" and the opportunity for each individual to argue for a free public space (Pri public spehare) and free to work according to the potential talents of each individual's interest, should not be limited to the rights of others, about the importance we maintain. "humanity", the nature and attitude of respecting all people and God's creation by cultivating and maintaining the qualities and the commendable attitude of appreciating and respecting the humanity of each person are noble deeds with Allah's side.

In the activity of inculcating character values and wisdom in early childhood, children are very urgent because our collective responsibility in children's daily lives will be reflected in children's attitudes and behavior and how to deal with personal problems. The authors argue that education is a process of intelligence through learning so that teachers and parents must be responsible for making someone not only to recognize the value of goodness alone but can make children aware of these virtues in everyday life for the realization of a tough character and a noble personality.

\section{Research Methods}

The research method used is qualitative research with a classroom action research approach that describes the process implementation of planting moderate Islamic character values through socialization and learning in early childhood. The subjects of this study were children in RA DWP IAIN Datokarama Palu, With a total of eleven boys and seven girls.

Data collection was carried out by observation, interview, and technique documentation. ${ }^{5}$ The data analysis technique used is data reduction, data presentation, and data verification using a character indicator rating scale by

\footnotetext{
${ }^{5}$ N. Nurdin, R. Stockdale, \& H. Scheepers, "The Use of Social Media to Gather Qualitative Data: A Case of Government E-Procurement Implementation and Use." 24th Australasian Conference on Information Systems (ACIS)
} 
measuring on the attitude scale BT (Unseen), MT (Beginning to appear), MB (Beginning to develop), MK (It has become a habit and has become a culture).

\section{Results and Discussion}

Basic Concepts of Moderate Islamic Values

The meaning of moderate Islam or Al-Wasathiyyah, comes from the word wasath, which has a meaning that revolves around the aspects of fair, good, middle, and balanced. ${ }^{6}$ Activities that prioritize a moderate attitude are indeed very consistent with the recommendations of other verses of the Qur'an that are in harmony, but it is necessary to realize from an early age that its implementation, for this there needs to be a pilot effort so that "moderation" or wasthiyyah can be a reference for thinking, behaving, and acting. Therefore, our response as religious moderation activists is urgent concerning the problems of Muslims, especially those related to extremities in religion, which are increasingly being shown by some Muslim circles lately. Therefore, the author argues that Islamic moderation or wasathiyyah is important to do through socialization and learning in early childhood.

The notion of moderate Islam is not without concepts and foundations. Instead, the term appears with a theological and ontological basis (something concrete). The term moderate Islam is part of universal Islamic teachings. The term moderate Islam is equivalent to the Arabic term ummatan wasathan or aldin al-wasath. Allah Almighty said in QS. Al-Baqarah: 143, namely:

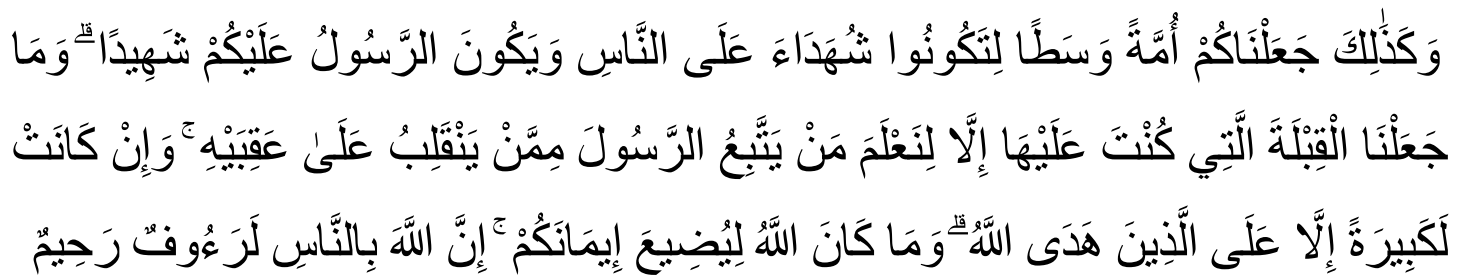

${ }^{6}$ Hanafi Muchlis, Moderasi Islam, Menangkal Radikalisme Berbasis Agama, (Jakarta: Pusat Studi AlQur'an (PSQ), 2013). 
Translation:

And thus we have made you a just community that you will be witnesses over the people and the Messenger will be a witness over you. And We did not make the qiblah which you used to face except that We might make evident who would follow the Messenger from who would turn back on his heels. And indeed, it is difficult except for those whom Allah has guided. And never would Allah have caused you to lose your faith. Indeed Allah is, to the people, Kind and Merciful. ${ }^{7}$

Umatan wasathan in this verse means "middle class or religion." The word "wasat" in the verse above, when referring to classical interpretations such as al-Tabari or al-Razi, has three possible meanings: people who are just, middle, or the best. The three meanings are, in essence, interrelated. As a survivor of Islamic moderation, they should give awareness to the younger generation, starting from the early childhood generation, that times have changed. Islam also appears as an exclusive (luxurious, and classy) teaching that cannot be in line with modernization. On the other hand, the spirit of prioritizing Islam as a religion that is always in line with the development of space and time has prompted several groups to provide conceptual views, thoughts from foreign cultures, and civilizations, which are currently dominated by materialistic views.

Moderate Islam is a religious group that can make peace in society and the state. Which, in the teachings, it is very contrary to Radical and Liberal Islam. Science and technology from the West is an absolute requirement for Muslim modernists. And it seems that these demands have yielded many results. And slowly, the Muslims rose and increasingly gained positions in their respective countries, including in Indonesia. The author can conclude that when we can understand the way of thinking of this moderate Islamic group, it seems that the negative side is almost non-existent because the way of thinking of this group can be accepted by reason and mind so that society

\footnotetext{
${ }^{7}$ Al-Jumanatul, Al-Qur'an dan Terjemahnya. (CV Penerbit J-ART, 2017)
} 
can properly accept the teachings of moderate Islam. And from the positive side, this group has the character of being open to other parties' opinions.

According to Qaradawi, Islam must be able to follow and balance the life of the nation and state. So that a harmonious life will be created that can create world peace. And the most important thing is the creation of the life that all humankind wants in this world and the hereafter does not show excessive fanaticism which results in a person closing himself off from other views, anticipating from an early age the excessive attitude in religion that will arise among the community (ummah).

The description in Islam itself has no definite reference to the concept of "moderate Islam." However, to build an Islam that is polite and willing to understand other groups, without reducing the actual principles of Islam, the concept of "moderate Islam" seems worthy of actualization. The problem is can those who are different can respect each other, not blame each other, do not state the most correctness of their own, and are willing to have a dialogue so that it is reflected that differences are truly a blessing. If this is used as a basis for charity and religion, then this is the true meaning of the concept of "moderate Islam." This means that anyone who is in religion can behave according to these criteria, it can be called moderate Islam. Although in Islam itself, the concept of "moderate Islam" does not have a definite reference, however, to develop a polite and willing Islam to understand other groups, without reducing the actual principles of Islam, the concept of "moderate Islam" seems worthy of actualization.

The Importance of Early Childhood Education as a Character Shaper

Child education as a forum for the formation of children's character from an early age, early childhood education has the following concept according to Law Number 20 of 2003 concerning the national education system Chapter I point 14, it is stated that "Early childhood education is an effort of guidance aimed at children since 
born up to the age of six, which is carried out by providing educational stimulus to assist growth and physical and spiritual development so that the child has the readiness to enter further education."

In the world of Islamic education, the character education process is not just providing insight through a verbalist approach, which tends to memorize and serve as an insight. However, this process must be able to encourage children to have good morals and be able to prevent them from carrying out despicable morals.

In this regard, Munir defines character as a pattern, be it thoughts, attitudes, or actions that are very strong and difficult to remove. ${ }^{9}$ Meanwhile, according to Hermowo, a character is nature or things that are very basic in a person. Furthermore, Hermowo also gives the meaning of character as morals or character that differentiates a person from another. ${ }^{10}$

Judging from these definitions, there is no significant difference in character and morals. Character and morals both show an action that is born spontaneously without thought to think about gain and loss. In other words, it can be called a habit.

Early Childhood Education aims to develop all the potential of children so that one day they can function as complete human beings. The concept of a whole human being is a conception of efforts to provide provisions for children to provide services and education, which can include various developments that accompany children's lives that help children's growth and development, including motor, social, language, and others.

Early Childhood Education is a form of education that focuses on laying the foundation towards the growth and development of children's mental, physical,

\footnotetext{
${ }^{8}$ Undang-Undang, Undang-Undang RI Nomor 20 tahun 2003 tentang Sistem Pendidikan Nasional, (Bandung: Citra Umbara, 2006), p. 2.

${ }^{9}$ Abdullah Munir, Pendidikan Karakter, (Yogyakarta: Pedagogia, 2010), p. 3.

${ }^{10}$ Hermowo, Self-Digesting: Alat Menjelajahi dan Mengurai diri, (Bandung: Mizan Media Utama,
} 2004), p. 175 
intelligence, intellectual power, spiritual, emotional creativity and language skills, communication, and social adaptability. Early Childhood Education is an education that involves all children, including concern for children's development, physical, cognitive, and social. Learning in early childhood is organized according to interests with children's learning styles.

Early childhood is a group of children who are in a unique process of growth and development, in the sense of having a growth and development pattern (fine and gross motor coordination), intelligence (thinking power, creativity, emotional intelligence, and spiritual intelligence), social-emotional (attitudes and behavior and religion), language and communication specifically following the level of growth and development of children. ${ }^{11}$

After knowing the meaning of early childhood, the following is explained about Early Childhood Education (PAUD). PAUD is a comprehensive process of fostering children's development from birth to six years, which includes both physical and nonphysical aspects by providing stimulation for physical, spiritual (moral and spiritual) development, motor, mind, emotional and social right so that children can grow and develop optimally. ${ }^{12}$

Early Childhood Education (PAUD) is a coaching effort aimed at children from birth to six years of age, which is carried out by providing educational stimulus to assist physical and spiritual growth and development so that children have the readiness to enter further education. ${ }^{13}$ Early Childhood Education (PAUD) is one of the stages of education that can determine the growth and development of children in the future. ${ }^{14}$

${ }^{11}$ Depdiknas, Kurikulum Hasil Belajar Pendidikan Anak Usia Dini, (Jakarta: Depdiknas, 2002), p. 3-

4.

${ }^{12}$ M. Iksan Kahar, Pendidikan Karakter pada Anak Usia Dini dalam Perspektif Islam, Musawa: Journal for Gender Studies, Vol 11(01) (2019): 123-150.

${ }^{13}$ Helmawati, Mengenal Dan Memahami PAUD, (Bandung: PT. Remaja Rosdakarya, 2015), p. 45.

${ }^{14}$ Suyadi, Maulidya Ulfah, Konsep Dasar PAUD, (Bandung: PT. Remaja Rosdakarya, 2015), p. 2. 
The efforts made include intellectual stimulation, health care, nutrition, and providing ample opportunities to explore and learn actively.

In the word of Allah SWT (Q.S. Ar-Ruum, [30]: 30), that is:

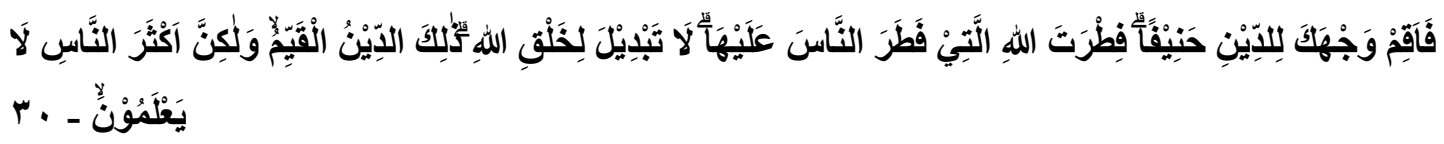

Translation:

'So turn your faces straight to the religion of Allah; (stay on) the nature of Allah Who has created humans according to that nature. there is no change in the nature of Allah. (That is) the straight religion; but most humans don't know ' (Q.S. Ar-Ruum, [30]: 30). ${ }^{15}$

Early childhood education in the perspective of Islamic education is an effort to help children so that their natural and non-physical abilities, both physical and nonphysical, can be fostered from an early age.

So, early childhood education aims to prepare physically and psychologically for primary school education by helping children express themselves and providing opportunities to practice their creativity, creativity, and imagination. Children have the confidence to move forward.

The objectives of Early Childhood Education itself include forming quality Indonesian children, that are children who grow and develop according to their level of development so that they have optimal readiness to enter basic education and navigate life in adulthood. Besides, Early Childhood Education also aims to help prepare children to achieve (academic) learning readiness in school ${ }^{16}$ Besides, Early Childhood Education aims to help lay the foundation towards the development of attitudes,

\footnotetext{
${ }^{15}$ Kementerian Agama RI, Al-Qur'an Tajwid dan Terjemahnya, (Bandung: PT. Sygma Examedia Arkanleema, 2012), p. 407.

${ }^{16}$ Maimunah Hasan, PAUD (Pendidikan Anak Usia Dini), (Yogyakarta: DIVA Press, 2010), p. 16-17.
} 
knowledge, skills, and creativity needed by students in adapting to their environment and for growth and development of social skills, as well as basic development through activities prepared by teachers including the development of language skills, thinking power, creativity, skills, and body. ${ }^{17}$

Education in the view of Islam is intended to increase spiritual potential and shape children to become human beings who believe and fear God Almighty and have noble character. Noble morals include ethics, manners, and morals as the manifestation of educational goals. The purpose of Islamic education is not only to form children who are faithful, have a noble character, do good deeds but also make these children knowledgeable and technological, also skilled and experienced so that they become independent people who are useful for themselves, their religion, their parents and their country. ${ }^{18}$

From the description above, it can be concluded that the purpose of education according to Islam is to form a Muslim who can carry out his obligations to Allah, as Allah has said in (Q.S. Adz-Dzariyaat, [51]: 56), that is:

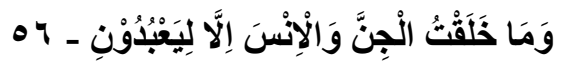

Translation:

'And I did not create jinn and humans but so that they would worship Me '(Q.S. Adz-Dzariyaat, [51]: 56). ${ }^{19}$

The meaning of the word worship in this verse is to monotheism Allah in all forms of worship. The purpose of education in Islam must be related to the goal of human creation itself in this world, which is to worship Allah SWT with all its aspects

${ }^{17}$ Moeslichatoen R, Metode Pengajaran di Taman Kanak-Kanak, (Cet. I; Jakarta: Rosda Karya, 2007), p. 3.

${ }^{18}$ Abuddin Nata, Kapita Selekta Pendidikan Islam, (Jakarta: PT. Raja Grafindo Persada, 2012), p. 140.

${ }^{19}$ Kementerian Agama RI, Al-Qur'an Tajwid dan Terjemahnya, (Bandung: PT. Sygma Examedia Arkanleema, 2012), p. 52. 
of worship, whether related to Allah, fellow humans, and with their environment. Worship is also related to ukhrowi (the hereafter) and worldly problems (world).

The goals of early childhood education are the same as the goals of education in general, but the goals of national education essentially provide motivation and incentives for the development of talents, interests, and potentials of children so that they can be channeled so that later they can become qualified generations of people who believe and fear Allah SWT. How early childhood can have character, noble character, healthy, knowledgeable, critical, creative, innovative and independent, confident, and able to become citizens of a democratic, responsible, and loving country in the future.

\section{Characteristics and Urgency of Early Childhood Learning}

Principles and characteristics of the implementation of early childhood education and learning, there are characteristics, and main principles that must be considered by teachers or education managers, among others: Prioritizing children's needs and learning that it is being carried out and always oriented towards the needs of early childhood because at that age range children need educational development to reach maximum maturity. Activities and learning activities that children need are when they can find out how to learn while playing, and children are free to explore, children are invited so that children can find something that suits their talents, use learning facilities and play facilities according to their needs and expectations through learning children can decide and draw conclusions what was done. How are the efforts of teachers and managers Raudhatul Atfal able to create a learning and playing environment that is conducive, interesting, and fun so that teachers are required to create an environment that is liked or favored by children so that children always have the desire to come to learn and play. What is the form of the teacher's efforts to create a meaningful learning system, therefore the teacher should use an integrated learning 
system and curriculum in all aspects of children's needs, be in learning activities, play activities, and creating creativity or even work, creating interesting themes that can generate learning power children and more meaningful for early childhood. Developing children's life skills so that children from an early age can have life skills that will later support their personal and family lives and can also have self-discipline.

The use of various sources that can be used as learning media or educational games that come from the surrounding environment can also be guided by children to use recycled objects as media and educational tools to care for the environment and foster an entrepreneurial spirit. Early childhood learning systems and structures should be tiered and begin with the concept of a view that is closest to the needs and close to the child's soul. Early childhood learning should use a repeated approach, in line with the principles of trial-and-error learning, whose meaning and meaning should never be afraid to try and repeating one day you will find the truth behind the mistakes made before so it is necessary to repeat it so that a better truth can be found.

Integrated Moderate Islamic Character Values in Early Childhood Learning

The author concludes that to respond to the fulfillment of the concept of the taxonomic domain as stated above, character education requires basic principles that are easy to understand and can be understood by students and by every individual who works in the educational environment itself (educators, educational staff and laboratory assistants). Several principles can be used to socialize and implement character education in schools. The author realizes that the character and values of life (values) that underlie students' behavior based on religious, cultural, legal, constitutional, ethical, and aesthetic norms, customs (indigenous) are essentially inherent from the root fibers of everyone. "Character is determined by what we do, not what we say or believe." Good character presumes that a good thing is done in a good way." 
Learning the values of moderate Islamic character values can be carried out well and maximally if all parties work together and do the same through policy or regulation of school leaders, as determinants of policies and the interests of a values-based educational institution. Learning activities, which are in addition to making students master the targeted competencies (material), are also designed to make students recognize, realize/care, and can internalize values and make them behave in their lives. ${ }^{20}$

The author argues that not all teaching and learning activities (PBM) in class show character education. The integration of character education in the learning process is carried out, starting from the planning, implementation, and evaluation stages of learning in all subjects. Among the principles that can be adopted in making lesson plans, implementing the learning process, and evaluating are the principles of contextual learning (Contextual Teaching and Learning). These principles are briefly described below. Aunnurrahman's opinion Constructivism is a learning theory which states that people construct or build their understanding from new experiences based on their initial knowledge and beliefs. The task of the teacher in constructive learning is to facilitate the learning process by (a) making knowledge meaningful and relevant to students, (b) allowing students to find and apply their ideas, (c) to make students aware of their strategies in learning. Constructivism learning in learning is divided into several phases: (a). Orientation, (b). Elicitation, (c). Restriction of ideas, (d). Application of ideas, Review As for the learning principles of Constructivism, (a). Knowledge is built by students, (b). Knowledge cannot be transferred (c). Students construct, (d). Educators only help to prepare conducive facilities and situations, (e). Confronting problems that are relevant to students (f). Learning around the main concepts, (g). Seeking (inquiry)

${ }^{20}$ Nurdin, N., Pettalongi, S. S., \& Ahsan, M. N. (2019). Implementation of Teaching Quality Assessment System Using Android. 2019 5th International Conference on Science and Technology (ICST) 
and assessing the opinions of students. (h). Curriculum development. Likewise, constructivism learning includes four stages: (a). Apperception, (b). Exploration, (c). Discussion and explanation of concepts, (d). Development and application.

In addition to the constructivism learning model, the concept of the Among learning system model is very identical and relevant to the description of national education, family education, humanitarian education, learning, and work is also initiated in education among diversity education and multicultural education. Reform, learn, and work without pressure and give freedom to think based on experience. Thus, the constructivism learning system also adheres to some of the same principles as the Among learning system so that these two systems can be integrated into learning.

The author concludes that (1) The two learning systems have many similarities in views and principles as a basis for designing and planning a learning design (instructional design). The values of moderate Islamic character values can be integrated into all the material being taught. (2) good learning in PAUD / RA institutions should be able to help students develop themselves optimally, and thus all activities carried out in the learning process can provide a pleasant learning experience and benefit students later.

The author hopes that with the integration of several systems, theories, and learning concepts, it can enrich the learning treasures of moderate Islamic character values in early childhood, which can be studied with constructivism learning approaches and the Among learning system. PAUD/RA institutions as a hone for the realization of polite, intelligent, and Islamic children and can be realized through PAUD/RA educational institutions, namely schools that are full of civilization, because the goal of learning globally is the formation of quality and quality education services and capable of empowering competitiveness. 


\section{Conclusion}

Early childhood education is one of the stages of education that cannot be ignored because it determines children's growth and development. Along with the growth and mental development of children, learning requires adequate service or guidance.

The character and values that underlie students' behavior based on religious, cultural, legal, constitutional, ethical, and aesthetic norms, customs (indigenous), are inherent from the root fibers of everyone. "Character is determined by what we do, not what we say or believe." Good character presumes that a good thing is done in a good way."

Learning the values of moderate Islamic character values can be carried out well and maximally if all parties work together and do the same through policy or regulation of school leaders, as determinants of policies and the interests of a valuesbased educational institution. Learning activities, in addition to making students master the targeted competencies (material), are also designed to make students know, realize/care, and can internalize values and make them behave in their lives.

\section{References}

Al- Qaradhawi, Yusuf. Ash- Shahwab al- Islamiyyah Bayna al - Jamud Wath Tatharuuf Kairo: Dar asy-swyuruq, Cet.I, 2001.

Al-Jumanatul, Al-Qur'an dan Terjemahnya. CV Penerbit J-ART. 2017.

Darling-Hammond, L., Flook, L., Cook-Harvey, C., Barron, B., \& Osher, D. (2020). Implications for educational practice of the science of learning and development. Applied Developmental Science, 24(2), 97-140. https://doi.org/10.1080/10888691.2018.1537791

Depdiknas, Kurikulum Hasil Belajar Pendidikan Anak Usia Dini, Jakarta: Depdiknas, 2002. 
Dobinson, T. (2001). Do learners learn from classroom interaction and does the teacher have a role to play? Language Teaching Research, 5(3), 189-211. https://doi.org/10.1177/136216880100500302

Evita, E., Syahid, A., \& Nurdin, N. (2019). Understanding Students' Learning Outcomes Differences Through the Application of the Market Place Activity Type of Cooperative Learning Model and the Application of Conventional Learning Models International Journal of Contemporary Islamic Education, 1(1), 67-85.

Hasan, Maimunah. PAUD (Pendidikan Anak Usia Dini), Yogyakarta: DIVA Press, 2010.

Helmawati, Mengenal Dan Memahami PAUD, Bandung: PT. Remaja Rosdakarya, 2015.

Hermowo, Self-Digesting: Alat Menjelajahi dan Mengurai Diri, Bandung: Mizan Media Utama, 2004.

Kahar, M. Iksan. Pendidikan Karakter pada Anak Usia Dini dalam Perspektif Islam, Musawa: Journal for Gender Studies, Vol 11(01) 2019.

Kementerian Agama RI, Al-Qur'an Tajwid dan Terjemahnya, Bandung: PT. Sygma Examedia Arkanleema, 2012.

Moeslichatoen R, Metode Pengajaran di Taman Kanak-Kanak, Cet. I; Jakarta: Rosda Karya, 2007.

Muchlis, Hanafi. Moderasi Islam, Menangkal Radikalisme Berbasis AgamaJakarta, Pusat Studi Al-Qur'an (PSQ), 2013.

Munir, Abdullah. Pendidikan Karakter, Yogyakarta: Pedagogia, 2010.

Nata, Abuddin. Kapita Selekta Pendidikan Islam, Jakarta: PT. Raja Grafindo Persada, 2012.

Nurdin, N., \& Aratusa, Z. C. (2020). Benchmarking level interactivity of Indonesia government university websites. TELKOMNIKA Telecommunication, Computing, Electronics and Control, 18(2), 853-859.

Nurdin, N., Pettalongi, S. S., \& Ahsan, M. N. (2019). Implementation of Teaching Quality Assessment System Using Android. 2019 5th International Conference on Science and Technology (ICST)

Nurdin, N., Stockdale, R., \& Scheepers, H. (2013). The Use of Social Media to Gather Qualitative Data: A Case of Government E-Procurement Implementation and Use. 24th Australasian Conference on Information Systems (ACIS)

Suyadi, Maulidya Ulfah, Konsep Dasar PAUD, Bandung: PT. Remaja Rosdakarya, 2015.

Undang-Undang, Undang-Undang RI Nomor 20 tahun 2003 tentang Sistem Pendidikan Nasional, Bandung: Citra Umbara, 2006. 
Jurnal Hunafa: Studia Islamika, Volume 17, Number 2, p. 1-190

E-ISSN: 2355-7710

P-ISSN: 1411-125X 